Print ISSN: 2502-1397 / Online ISSN 2540-8100

https://doi.org/10.32505/j-ebis.v6i1.2683

\title{
PERAN BAITUL MAL SEBAGAI PENGHIMPUN DANA ZAKAT DALAM MENANGGULANGI KEMISKINAN DI KOTA LANGSA
}

\author{
Mulyadi*, Fathahillah** \\ * Institut Agama Islam Negeri Langsa, mulyadi@iainlangsa.ac.id \\ **Institut Agama Islam Negeri Langsa, fathahsn77@gmail.com
}

\begin{abstract}
Aceh is one of the provinces with a high poverty rate and is also a region with a high poverty rate in Sumatra, including Langsa City. Therefore, one of the efforts to alleviate poverty in Langsa City is by utilizing zakat funds managed by the Baitul Mal Institute, which will later be distributed to the poor in Langsa City. This study aims to identify the role of the Baitul Mal Institution in alleviating poverty and improving the welfare of the people of Langsa City. From the research results, it is concluded that the distribution of zakat funds to the poor is still ineffective and still not on target so that people still do not feel prosperity.
\end{abstract}

Keyword: Baitul mal, zakat funds, poverty

\begin{abstract}
Abstrak
Aceh merupakan salah satu provinsi yang tingkat kemiskinannya tinggi dan juga merupakan daerah yang tingkat kemiskinannya tinggi di sumatera, termasukKota Langsa. Maka dari itu, salah satu upaya untuk menanggulangi kemiskinan di Kota Langsa yaitu dengan memanfaatkan dana zakat yang dikelola oleh Lembaga Baitul Mal yang nantinya dana tersebut disalurkan kepada masyarakat miskin di Kota Langsa. Penelitian ini bertujuan untuk mengidentifikasi peran dari Lembaga Baitul Mal dalam mengentaskan kemiskinan serta meningkatkan kesejahteraan masyarakat Kota Langsa. Dari hasil penelitian, disimpulkan bahwa penyaluran dana zakat kepada masyarakat miskin masih belum efektif dan masih belum tepat sasaran sehingga masyarakat masih belum merasakan kesejahteraan.
\end{abstract}

\section{Kata kunci : Baitul Mal, Dana Zakat, Kemiskinan}

\section{PENDAHULUAN}

Kemiskinan merupakan sebuah permasalahan yang melanda banyak umat. Rendahnya taraf ekonomi ternyata dialami oleh masyarakat muslim dan menjadi pusat perhatian. Islam memerangi kemiskinan, tidak hanya miskin sebagai akibat, melainkan memberantas faktor-faktor penyebab kemiskinan, kebodohan, pola pikir dan semangat hidup yang tidak benar (Abdurrachman Qadir, 2007)

Di Indonesia, provinsi yang tingkat kemiskinannya relatif tinggi salah satunya yaitu Aceh, dan juga merupakan daerah dengan tingkat kemiskinan 
tertinggi di sumatera. Seiring dengan tingginya tingkat kemiskinan di Aceh, ketimpangan pendapatan juga relatif berpengaruh mengalami kenaikan (Amri, 2017). Tingginya tingkat kemiskinan dan ketimpangan pendapatan merupakan suatu tantangan bagi pemerintah Aceh, termasuk Kota Langsa dalam mewujudkan kesejahteraan dan mengurangi tingkat kemiskinan tersebut (Amri \& Nazamuddin, 2018).

Salah satu upaya pemerintah dalam menanggulangi kemiskinan yaitu dengan dilakukannya pemanfaatan dari dana zakat oleh suatu lembaga yang disebut dengan Baitul Mal. Dengan adanya lembaga tersebut, pengelolaan dan pemanfaatan dana zakat yang dihimpun dapat dilakukan secara optimal dan terkoordinir dengan baik. Selain dari itu, lembaga Baitul Mal juga berperan sebagai lembaga yang menyalurkan dana zakat kepada orang-orang yang berhak menerimanya.

Pada saat ini, keberadaan Baitul Mal Kota Langsa ternyata masih belum efektif dalam menurunkan jumlah masyarakat miskin di Kota Langsa. Hal ini dibuktikan dengan masih banyaknya masyarakat Kota Langsa yang hidup serba kekurangan. Maka, diperlukannya solusi yang saling mendukung antara satu dengan lainnya. Salah satunya yaitu dengan mengoptimalkan peran Baitul Mal di Kota Langsa.

Lahirnya Baitul Mal di provinsi Aceh diatur dibawah Undang-Undang otonomi daerah istimewa Aceh dalam bentuk Qanun zakat dan zakat diakui sebagai pendapatan asli daerah (PAD) provinsi Aceh . Sementara itu Qanun zakat yang lahir di Provinsi Aceh yang menerangkan struktur lembaga Baitul Mal dimulai dengan Baitul Mal Aceh (BMA) pada tingkat provinsi (pasal 4), Baitul Mal Kabupaten/ Kota pada tingkat kabupaten (pasal 5) dan Baitul Mal Gampong tingkat Desa (pasal 6) (Himpunan Peraturan Perundang-Undangan Baitul Mal Aceh, 2012). Lahirnya susunan organisasi tersebut membuktikan bahwa akses yang dibangun untuk memaksimalkan penghimpunan zakat sangat baik. Hal ini akan mempermudah muzakki untuk menunaikan zakatnya dimanapun mereka tinggal.

Disini peneliti mengambil kesimpulan bahwa masalah yang di hadapi yaitu kurang optimalnya peran Baitul Mal sebagai penghimpun dana zakat dalam hal menanggulangi tingkat kemiskinan di Kota Langsa yang bertujuan untuk meningkatkan kesejahteraan. 


\section{LANDASAN TEORETIS}

\section{Baitul Mal}

Bay al-mal berasal dari bahasa Arab yaitu dari kata bait, yang berati rumah. Dan al-mal yang berarti harta. Jadi secara etimologis, Baitul Mal berarti rumah untuk mengumpulkan atau menyimpan harta (A. Djazuli dan Yadi Janwari, 2002) . sedangkan secara terminologis, Baitul Mal adalah suatu lembaga atau pihak yang mempunyai tugas khusus menangani segala harta umat, baik berupa pendapatan maupun pengeluaran negara. Jadi setiap harta baik berupa tanah, bangunan, barang tambang, uang komoditas perdagangan, maupun harta benda lainnya yang kaum muslim berhak memilikinya sesuai ketentuan syara' dan tidak ditentukan individu pemiliknya, walaupun telah tertentu pihak yang berhak menerimanya, maka harta tersebut menjadi hak Baitul Mal, baik yang sudah benar-benar masuk ke dalam tempat penyimpanan Baitul Mal maupun yang belum.

Setiap harta yang wajib dikeluarkan untuk orang-orang yang berhak menerimanya, atau untuk merealisasikan kemaslahatan kaum muslimin, atau biaya penyebarluasan dakwah adalah harta yang dicatat sebagai pengeluaran Baitul Mal, baik yang telah dikeluarkan secara nyata maupun yang masih berada dalam penyimpanan Baitul Mal.

Definisi lain yang menyatakan bahwa Baitul Mal adalah rumah harta, gedung pembendaharaan negara yang menyimpan sekian kekayaan harta negara dan tempat pengaturan segala sesuatu yang bersnagkutan dengan harta negara tersebut. Di zaman Rasulullah SAW pemungutan zakat dan lainnya sebagai sumber pendapatan negara pada masa itu belum memerlukan administrasi yang luas, hal ini terjadi karena jumlah umat muslim yang masih terbatas (Abdul Dkk, 1997).

\section{Zakat}

Zakat secara etimologi yang dikutip oleh Yusuf Al-Qardhawi adalah kata dasar yang berarti berkah, tumbuh, bersih dan baik (Ali Ridlo, 2014). Sesuatu yang dikatakan zaka yang berarti tumbuh dan berkembang, dan seseorang itu dapat dikatakan zaka, yang berarti bahwa orang itu baik.

Pendapat Sulaiman Rasyid mengatakan bahwa zakat secara terminologi adalah kadar harta tertentu yang diberikan kepada yang berhak menerimanya dengan beberapa syarat. Setiap umat muslim wajib mengeluarkan zakat apabila 
telah cukup memenuhi syarat wajib zakat yang kemudian diserahkan kepada mustahiq.

Hikmah zakat terbagi menjadi tiga aspek diantarnya sebagai berikut :

1. Faidah diniyyah (segi agama)

a. Berzakat mengantarkan seorang hamba kepada kebahagiaan dan keselamatan dunia dan akhirat

b. Sarana bagi hamba untuk taqarrub (mendekatkan diri) kepada Allah, akan menambah keimanan karena ketaatannya

c. Pembayar zakat akan mendapatkan pahala besar yang berlipat ganda

d. Zakat merupakan sarana penghapus dosa

2. Faidah khuluqiyyah (segi akhlak)

a. Menanamkan sifat kemuliaan, rasa toleran dan lapang dada kepada pribadi pembayar zakat

b. Pembayar zakat identik dengan sifat belas kasih dan lembut kepada saudaranya yang kurang mampu

c. Merupakan ealita bahwa menyumbang sesuatu raga bagi kaum muslimin akan melapangkan dada dan meluaskan jiwa sebab sudah pasti ia akan menjadi orang yang dicintai dan dihormati sesuai dengan tingkat pengorbanannya.

d. Terdapat penyucian terhadap akhlak.

3. Faidah ijtimaiyyah

a. Zakat merupakan sarana untuk membantu dalam memenuhi hajat hidup para fakir miskin yang merupakan kelompo mayoritas sebagian besar negara di dunia

b. Memberikan support kekuatan bagi kaum muslimin dan mengangkat eksistensi mereka. Hal ini bisa dilihat dalam kelompok penerimaan zakat, salah satunya adalah mujahidin fi sabilillah.

c. Zakat bisa mengurangi kecemburuan sosial. Dendam dan rasa dongkol yang ada dalam dada fakir miskin karena masyarakat bawah akan mudah tersulut rasa benci dan permusuhan jika mereka melihat kelompok masyarakat ekonomi tinggi menghambur-hamburkan harta yang demikian melimpah untuk mengentaskan kemiskinan tentu akan terjalin keharmonisan dan cinta kasih antara si kaya dan si miskin. 
d. Zakat akan mengacu pertumbuhan ekonomi pelakunya dan yang jelas berkahnya akan melimpah ruah.

e. Membayar zakat berarti memperluas peredaran harta benda atau uang, karena ketika harta dibelanjakan maka perputarannya akan meluas dan lebih banyak pihak yang mengambil manfaat.

\section{Kemiskinan}

Definisi tentang kemiskinan bermacam-macam, mulai dari sekedar ketidakmampuan memenuhi kebutuhan konsumsi dasar memperbaiki keadaan, kurangnya kesempatan berusaha hingga pengertian yang lebih luas yang memasukkan aspek sosial dan moral (Saleh, 2002).

Dalam arti sempit, kemiskinan dipahami sebagai keadaan kekurangan uang dan barang untuk menjamin kelangsungan hidup. Sedangkan dalam arti luas, kemiskinan merupakan suatu fenomena multiface atau multidimensional (Hamudy, 2008).

Menurut kurniawan, kemiskinan adalah apabila pendapatan suatukomunitas berada di bawah satu garis kemiskinan tertentu. Kemiskinan juga dianggap sebagai bentuk permasalahan pembangunan yang diakibatkan adanya dampak negatif dari pertumbuhan ekonomi yang tidak seimbang, sehingga memperlebar kesenjangan pendapatan antar masyarakat maupun kesenjangan pendapatan antar daerah.

Kondisi masyarakat yang disebut miskin dapat diketahui berdasarkan kemampuan pendapatan dalam memenuhi standar hidup. Pada prinsipnya, standar hidup di suatu masyarakat tidak sekedar tercukupinya kebutuhan akan pangan, akan tetapi tercukupinya kebutuhan akan kesehatan maupun pendidikan. Tempat tinggal ataupun permukiman yang layak merupakan salah satu dari standra hidup atau standar kesejahteraan masyarakat di suatu daerah.

Kemiskinan merupakan suatu keadaan, sering dihubungkan dengan kebuuhan kesulitan dan kekurangan di berbagai keadaan hidup. Sebagian orang memahami istilah ini secara subyektif dan komparatif, sementara yang lainnya melihat dari segi moral dan evaluatif dan lainnya memahami dari sugut ilmiah yang telah mapan. Istilah "negara berkembang" biasanya digunakan untuk merunjuk kepada negara-negara yang miskin. 
Kemiskinan dipahami dalam berbagai cara, pemahaman utamanya mencakup :

1. Gambaran kekurangan materi, yang biasanya mencakup kebutuhan pangan sehari-hari, sandang dan pelayanan kesehatan. Kemiskinan dalam arti ini dipahami sebagai situasi barang dan pelayanan dasar.

2. Gambaran tentang kebutuhan sosial, termasuk keterkucilan sosial, ketergantungan dan ketidakmampuan untuk berpartisipasi dalam masyarakat. Keterkucilan sosial biasanya dibedakan dari kemiskinan, karena hal ini mencakup masalah-masalah politik dan moral dan tidak dibatasi pada bidang ekonomi.

3. Gambaran tentang kurangnya penghasilan dan kekayaan yang memadai. Makna "memadai" disini sangat berbeda-beda melintasi bagian-bagian politik dan ekonomi di seluruh dunia (Abad Badruzzaman, 2007).

\section{Faktor Penyebab Kemiskinan}

Faktor utama penyebab kemiskinan adalah sikap berdiam diri, enggan atau tidak dapat bergerak dan berusaha. Keengganan berusaha adalah penganiayaan terhadap diri sendiri, sedangkan ketidakmampuan berusaha antara lain disebabkanoleh penganiayaan manusia lain (Quraish Shihab, 2010).

Ada beberapa faktor lain yang menyebabkan kemiskinan, yaitu sebagai berikut :

1. Malas bekerja

Sikap malas merupakan suatu masalah yang cukup memperhatikan, karena masalah ini merupakan mentalitas dan kepribadian seseorang. Adanya sikap malas, seseorang bersikap acuh tak acuh dan tidak berkeinginan untuk bekerja atau bersikap pasif dalam hidupnya (sikap bersandar pada nasib).

2. Pendidikan yang terlampau rendah

Adanya tingkat pendidikan yang rendah menyebabkan seseorang kurang mempunyai keterampilan tertentu yang diperlukan dalam kehidupannya. Keterbatasan pendidikan atau keterampilan yang dimiliki menyebabkan keterbatasan kemampuan untuk masuk dalam dunia kerja.

3. Terbatasnya lapangan pekerjaan

Faktor ini akan membawa konsekuensi kemiskinan bagi masyarakat. Secara ideal banyak orang mengatakan bahwa seseorang atau masyarakat harus mampu 
menciptakan lapangan kerja baru, tetapi secara faktual hal tersebut kecil kemungkinan karena adanya keterbatasan kemampuan seseorang baik berupa skill maupun modal.

4. Keterbatasan sumber daya alam

Kemiskinan akan melanda suatu masyarakat apabila sumber daya alamnya tidak lagi memberikan keuntungan bagi kehidupan mereka. Sering dikatakan bahwa, masyarakat miskin karena dasar alamnya miskin.

\section{Keterbatasan modal}

Merupakan sebuah kenyataan yang ada di negara-negara yang sedang berkembang. Kenyataan tersebut membawa kemiskinan pada sebagian besar masyarakat di negara tersebut. Seseorang miskin sebab mereka tidak mempunyai modal untuk melengkapi alat ataupun bahan dalam rangka menerapkan keterampilan yang mereka miliki dengan suatu tujuan untuk memperoleh penghasilan.

\section{Beban keluarga}

Semakin banyak anggota keluarga akan semakin meningkat tuntutan atau beban hidup yang harus dipenuhi. Seseorang yang mempunyai anggota keluarga yang banyak, apabila diimbangi dengan usaha peningkatan pendapatan akan menimbulkan kemiskinan karena mereka berangkat dari kemiskinan.

7. Etos kerja yang rendah

Rendahnya etos kerja dapat disebabkan oleh berbagai faktor, misalnya kebiasaan hidup santai dan hanya suka menikmati tanpa mau bekerja keras dan faktor-faktor lainnya yang banyak ditemukan di masyarakat.

8. Salah paham terhadap ajaran Islam

Faktor ini meliputi beberapa hal yang dianggap umum terjadi, awalnya disebabkan oleh kesalahpahaman dalam penafsiran terhadap ajaran Islam dan terlebih lagi mereka yang taat beragaman, tidak menyentuh tuntutan kemajuan ekonomi di dunia yaitu ajaran-ajaran yang ada pada intinya menjauh dari hiruk pikuk keduniaan dan memfokuskan pada keakhiratan berupa ibadah murni yang justru mendapatkan penekanan oleh para mubalig dan ustadz. 


\section{Dampak dari kemiskinan}

1. Kemiskinan membahayakan akidah

Kemiskinan adalah ancaman yang serius terhadap akidah, terkhusus bagi kaum miskin yang bermukim di lingkungan kaum berada. Terlebih jika kaum miskin bekerja dengan susah payah, sementara golongan kaya hanya bersenangsenang. Ini akan berdampak timbulnya penyimpangan akidah dan kemiskinan yang dapat mengakibatkan kekafiran.

2. Kemiskinan membahayakan akhlak dan moral

Jika kaum miskin hidup di lingkungan golongan kaya yang tamak, maka kemelaratan dan kesengsaraan itu akan mendorong ia untuk melakukan pelanggaran atau kejahatan dimana kesengsaraan itu dapat mengakibatkan seseorang meragukan nilai-nilai akhlak dan agama.

3. Kemiskinan mengancam kestabilan pemikiran

Malapetaka kekafiran dan kemiskinan tidak hanya terbatas pada sisi rohani dan akhlak melainkan juga mengancam sisi pemikiran manusia. Bagaimana mungkin seorang miskin yang tidak mampu memenuhi kebutuhan pokok dirinya beserta keluarga dapat berfikir dengan baik, jika tetangganya hidup mewah ? itu akan mengganggu pemikirannya.

4. Kemiskinan membahayakan keluarga

Dilihat dari pembentukan keluarga, kemiskinan merupakan rintangan yang besar bagi pemuda untuk melangsungkan pernikahan yaitu memenuhi berbagai syarat seperti mahar, nafkah dan kemandirian ekonomi. Kemudian kemiskinan juga dapat memisahkan sepasang suami istri. Dan kemiskinan juga dapat merenggangkan hubungan keluarga.

\section{METODE}

Penelitian ini menggunakan metode kualitatif. Yang menjadi fokus dalam penelitian ini yaitu peran Lembaga Baitul Mal dalam menanggulangi atau mengurangi ttingkat kemiskinan di Kota Langsa. Data dalam penelitian ini terdiri dari data primer dan sekunder. Sumber data terdiri dari hasil wawancara, pengamatan, dokumen/arsip serta observasi lapangan. Teknik analisis data digunakan teknik analisis data deskriptif kualitatif dimana jenis data yang berbentuk informasi baik lisan maupun tulisan yang sifatnya bukan angka. 


\section{HASIL DAN PEMBAHASAN}

\section{Baitul Mal Kota Langsa}

Pada tanggal 6 April 2006, didirikannya Lembaga Baitul Mal Kota Langsa dimana keberadaan lembaga ini merupakan kesinambungan dari BAZIS dengan kewenangan yang luas sesuai dengan status khusus yang dimiliki oleh provvinsi Aceh. Kewenangan tersebut tertuang dalam Undang-undang Nomor 11 Tahun 2006 tentang pemerintah Aceh yang berbunyi "zakat harta wakaf dan harta agama dikelola oleh lembaga Baitul Mal Aceh dan Baitul Mal Kabupaten/Kota.

Keberadaan Lembaga ini semakin kuat setelah lahirnya Qanun Aceh Nomor 10 Tahun 2007 tentang Baitul Mal. Pada pasal 2 qanun ini, mendefinisikan Baitul Mal sebagai lembaga daerah non struktural yang melaksanakan tugasnya secara independen sesuai dengan syara' dan bertanggung jawab kepada pemimpin daerah.

Baitul Mal diberi kewenangan untuk mengurus, mengelola, mengumpulkan, menyalurkan serta mendayagunakan zakat. Pengumpulan zakat dilakukan dengan cara menerima atau mengambil dari orang yang mengeluarkan zakat (muzakki) berdasarkan pemberitahuan muzakki.

Program pemberdayaan lembaga Baitul Mal yang telah berjalan, diantanya sebagai berikut :

1. Penyaluran zakat konsumtif untuk para muztahiq yang rutin dilaksanakan pada setiap tahun

2. Membangun/merehap rumah-rumah bagi para mustahiq yang masih tinggal di tempat-tempat yang tidak layah huni

3. Mengirim para pelajar potensial dari keluarga yang kurang mampu untuk mengikuti pendidikan tahfizul Qur'an melalui program beasiswa penuh

4. Memberikan bantuan biaya pengajian bagi para muallaf yang memiliki komitmen memperdayakan keislamannya dengan belajar di dayah/pesantren

5. Bantuan rehab mesjid dan mushalla yang sedang dalam pembangunan

6. Pengajian rutin muallaf sekota Langsa

7. Memberikan bantuan berupa sembako kepada anak asuh yang berada di panti asuhan sekota Langsa

8. Bantuan Reposif tanggap darurat musibah dan bencana alam

9. Bantuan fakir uzhur setiap bulannya yang dibagikan per enam bulan sekali dalam setahun 
10. Pembangunan komplek pembinaan muallaf

11. Penyaluran senif fisabilillah dengan program safari maghrib walikota Langsa

12. Bantuan untuk penjaga pasien rujukan (brosur Baitul Mal Kota Langsa)

Baitul Mal sebagai penghimpun dana zakat dari para muzakki mengelola dana dan disalurkan kepada pihak yang membutuhkan yaitu fakir, miskin, fisabilillah, ibnu sabil, gharimin, muallaf, dan amil sebesar Rp.150.000.

Dalam rangka menyejahterkan masyarakat miskin, lembaga Baitul Mal memberikan bantuan berupa modal dengan sistem menerima proposal (permohonan), mendata proposal, survey, analisis kelayakan, realisasi bantuan, kemudian membuat laporan.

Selanjutnya terdapat beberapa program zakat yang tepat sasaran yang ditujukan untuk masyarakat miskin yaitu dalam bentuk uang tunai dengan bersosialisasi ke kampung-kampung untuk mendata masyarakat yang rumahnya sudah tidak layak huni dan memiliki penghasilan yang jauh dari kata cukup.

Dengan demikian, program kerja di lembaga ini masih ada yang belum optimal pelaksanaannya dikarenakan program tersebut tidak terlaksana dengan baik dan belum maksimal pelaksanaannya.

\section{Kendala dalam mengoptimalkan penyaluran dana zakat}

Setelah dana umat terkumpul, Baitul Mal Kota Langsa bertugas mendistribusikan dana tersebut kepada masyarakat yang membutuhkan. Namun, implementasinya timbul permasalahan terhadap tujuan dalam pendistribusiannya. Hal ini disebabkan oleh lembaga Baitul Mal dalam menerima data kurang teliti atas kinerja geuchik dan imam dalam mendata nama-nama orang yang berhak untuk menerima zakat. Dimana sebenarnya masyarakat tersebut berhak menerima bantuan malah tidak dapat bantuan karena salah sasaran.

Menurut Baitul Mal, kriteria masyarakat miskin belum ada karena mereka Cuma melihat langsung dan menilai apakah mustahiq tersebut layak dibantu atau tidak. Seharusnya Baitul Mal harus mempunyai kriteria-kriteria masyarakat miskin di kota Langsa. Dengan dilakukannya sosialisasi sesering mungkin, maka dapat membantu meningkatkan pengumpulan dana zakat sehingga dana tersebut dapat disalurkan kepada masyarakat miskin secara merata di Kota Langsa. 
Pada akhirnya, Baitul Mal Kota Langsa masih belum mampu menanggulangi masyarakat miskin di Kota Langsa. Berikut penyebabnya :

1. Pelaksanaan sosialisasi dengan memperkenalkan pentingnya Baitul Mal dengan pendekatan teknologi informasi. Hal ini sangat penting seiring dengan berjalannya zaman yang semakin lama semakin modern.

2. Baitul Mal belum menggunakan komunikasi informasi menghimpun dana zakat melalui instansi atau lembaga pemerintah maupun swasta.

\section{SIMPULAN}

Lembaga Baitul Mal belum optimal dalam menyalurkan dana zakatnya yang bertujuan untuk mengurangi tingkat kemiskinan di Kota Langsa dikarenakan lembaga tersebut masih memperoleh dana bantuan yang masih minim yang disebabkan muzakki kurang percaya untuk membayar zakatnya ke Lembaga Baitul Mal dan pihak lembaga tersebut juga belum tepat sasaran dalam menyalurkan dana zakatnya. Hal inilah yang menyebabkan Baitul Mal belum optimal dalam menyalurkan dana nya kepada masyarakat miskin di Kota Langsa.

\section{PUSTAKA ACUAN}

Abdul dkk. (1997).Kamus istilah figh. Kuala Lumpur: PT. Pustaka Firdaus.

Amri, K. (2017). Analisis pertumbuhan ekonom dan ketimpangan pendapatan: Panel data 8 Provinsi di Sumatera. Jurnal Ekonomi dan Manajemen Teknologi, 1(1),1-11.

Amri, K dan Nazamuddin. (2018). Is there causality relationship between economic growth and income inequality? Panel data evidence from Indonesia, Eurasian Journal of economic and finance, 6(2), 8-20

Badruzaman, abad. (2007). Teologi kaum tertindas: Kajian Tematik ayat-ayat mustad'afin dengan pendekatan keindonesiaan. Yogyakarta: Pustaka Pelajar.

Djazuli Ahmad dan Janwari Yadi. (2002). Lembaga Perekonomian Umat sebuah pengalaman, Jakarta: Raja Grafindo Persada.

Hamudy, M.I.A . (2008). Pengentasan rakyat miskin dan pembangunan manusia di Jawa Barat. Bandung: PPS FISIP UNPAD.

Himpunan peraturan perundang-undangan Baitul Mal Aceh sekretariat Baitul Mal Aceh. 2012

Qadir. Abdrahman. (2007). Zakat dalam dimensi Mahdah dan sosial, ed.1, cet. 2. Jakarta: Raja Grafindo Persada. 
Quraish. Shihab. (2010). Wawasan Al-Qur'an : Tafsir tematik atas berbagai persoalan umat. Bandung: Mizan.

Ridlo. Ali. (2014). Analisis efisiensi keuangan BAZNAS, Yogyakarta: Tesis. Program Pascasarjana UIN Sunan Kalijaga.

Saleh. S . (2002). Faktor-faktor penentu tingkat kemiskinan Regional di Indonesia. Economic Journal of emerging markets, 7(2): 87-102 